\title{
Magnesium therapy improves thromboelasto- graphic findings before liver transplantation: a preliminary study
}

\author{
[Un traitement au magnésium améliore les résultats thromboélastographiques \\ avant la transplantation hépatique : une étude préliminaire]
}

Jong H. Choi MD, Jaemin Lee MD, Chong M. Park MD

\begin{abstract}
Purpose: Patients undergoing liver transplantation may be predisposed to hypomagnesemia and present a bleeding tendency. There are evidences suggesting that magnesium is a crucial constituent of the blood coagulation cascade and has a pro-coagulant activity. The aim of this study was to investigate the effect of magnesium therapy on thromboelastography (TEG) in patients undergoing liver transplantation.
\end{abstract}

Methods: 27 patients scheduled for liver transplantation were enrolled. $1.5 \mathrm{~g}$ of magnesium sulfate, diluted in normal saline, were infused to all patients over five minutes in the operating room, before skin incision. The TEG findings immediately before and ten minutes after the magnesium infusion were compared.

Results: The TEG findings showed general hypocoagulability before magnesium therapy. The $\mathrm{K}$ time and coagulation times $(r+k)$ were shortened significantly from 64I.6 \pm 505.9 (mean \pm SD) to $464.6 \pm 387.7 \mathrm{sec}$ and from $1664.7 \pm 772.5$ to $1362.2 \pm 487.1$ sec respectively $(P<0.05)$; the maximal amplitude, and TEG index showed significant increases from $38.5 \pm 13.5$ to $45.3 \pm 12.2 \mathrm{~mm}$ and from $-3.4 \pm 2.6$ to $-1.9 \pm 1.8$ respectively after magnesium therapy $(P<0.01)$. R time, alpha angle and LY60 were not different after magnesium therapy.

Conclusion: Magnesium therapy significantly improved TEG findings suggestive of a general hypocoagulable state towards normal in patients about to receive liver transplantation.

\begin{abstract}
Objectif : Les patients qui subissent une transplantation hépatique peuvent être prédisposés à l'hypomagnésiémie et ont une tendance aux saignements. Il y a des indications que le magnésium soit un constituant capital de la réaction en cascade de la coagulation du sang et qu'il possède une activité procoagulante. Nous voulions examiner l'effet du magnésium sur la thromboélastographie (TEG) avant une greffe du foie.
\end{abstract}

Méthode : Nous avons recruté 27 patients devant subir une transplantation hépatique réglée. Pendant 5 min, I,5 g de sulfate de magnésium dilué dans une solution salée ont été perfusés chez tous les patients dans la salle d'opération, avant l'incision cutanée. Les résultats de la TEG obtenus immédiatement avant et dix minutes après la perfusion ont été comparés.

Résultats : La TEG a montré une hypocoagulabilité générale avant le traitement au magnésium. Le temps $K$ et les temps de coagulation ( $r$ $+k$ ) ont été significativement réduits de 641,6 \pm 505,9 (moyenne \pm écart type) à 464,6 \pm 387,7 s et de 1664,7 \pm 772,5 à 1362,2 \pm 487 , I s respectivement $(P<0,05)$; l'amplitude maximale et l'index TEG ont montré des hausses significatives de 38,5 \pm 13,5 à 45,3 $\pm 12,2 \mathrm{~mm}$ et de $-3,4 \pm 2,6$ à $-1,9 \pm 1,8$ respectivement, après le traitement au magnésium $(P<0,01)$. Le temps $R$, l'angle alpha et LY60 n'étaient pas différents après le magnésium.

Conclusion : Le traitement au magnésium améliore significativement les résultats de la TEG, suggérant un état général hypocoagulable par rapport à la normale chez les patients sur le point de recevoir une transplantation hépatique.

From the Department of Anesthesiology, School of Medicine, The Catholic University of Korea, Seoul, Korea. Address correspondence to: Dr. Jaemin Lee, Department of Anesthesiology, School of Medicine, The Catholic University of Korea,

Kangnam Saint Mary's Hospital, 505 Banpo-Dong, Seocho-Gu, Seoul, Korea 137-040. Phone: 82-2-590-1545; Fax: 82-2-537-1951;

E-mail: jmlee@catholic.ac.kr

Accepted for publication July 29, 2004.

Revision accepted November 8, 2004. 
$\mathrm{P}$ ATIENTS with end-stage liver disease usually show hypomagnesemia before liver transplantation due to decreased intake and gastrointestinal absorption of magnesium, increased excretion of magnesium due to laxatives used to prevent hepatic coma and diuretics used to treat ascites, and is accompanied by hypokalemia and hypocalcemia. ${ }^{1,2}$ Hypomagnesemia worsens during liver transplantation, because of massive blood transfusion since the anticoagulant citrate absorbs magnesium as well as calcium ions and causes cardiovascular instability such as the development of perioperative cardiac arrhythmia. ${ }^{3}$

Magnesium is known to be crucial physiologically in the coagulation cascade. According to recent studies, magnesium is an essential factor in the activation of coagulation factors and functions as a promoter of coagulation. ${ }^{4-6}$ Coagulation is impaired in patients with end-stage liver disease due to various factors such as decreased production of coagulation factors, gastrointestinal bleeding, splenomegaly, malnutrition and massive blood transfusion during liver transplantation. Considering the effect of magnesium on coagulation, we assumed that hypomagnesemia in patients with end-stage liver disease could impair coagulation and increase their tendency to bleed.

In this preliminary study, we examined the changes brought about by magnesium therapy on coagulation in patients about to undergo liver transplantation, using thromboelastography (TEG).

\section{Methods}

The study was conducted in 27 patients with endstage liver disease who underwent living-donor liver transplantation from April to November 2003.

After induction of anesthesia, a 20-gauge catheter was inserted in the right radial artery to monitor arterial pressure and to obtain blood samples for arterial blood gas analysis and TEG. Heparin was not added to the pressurized infusion system to prevent changes in
TEG. Two millilitres of whole blood were obtained through the right radial artery using the two-syringe technique after anesthesia induction. TEG analysis was performed using $0.36 \mathrm{~mL}$ of this blood sample. After $1.5 \mathrm{~g}$ of magnesium sulfate $\left(\mathrm{MgSO}_{4}\right)$ mixed in $100 \mathrm{~mL}$ of normal saline were infused $i v$ in five minutes, a blood sample was obtained ten minutes later to determine TEG changes. Other than magnesium, no drug was infused between blood samples. Furthermore, since the surgical procedure itself could promote blood coagulation, ${ }^{7}$ blood sampling for TEG analysis before and after magnesium therapy was completed before skin incision. The remaining blood samples were sent to the laboratory to measure the serum magnesium concentration before and after magnesium therapy.

Statistical treatment of all data was done using SPSS 11.0 (SPSS Inc., Chicago, IL, USA). The TEG variables including $\mathrm{R}$ time, $\mathrm{K}$ time, coagulation time $(\mathrm{r}+\mathrm{k})$, alpha angle, maximal amplitude (MA), TEG index and serum magnesium concentration were analyzed using Bonferroni $t$ tests. Non-parametric data including LY60 were analyzed using Wilcoxon sign test. $P$ values less than 0.05 were considered statistically significant.

\section{Results}

Representative TEG traces are shown in the Figure. Numerical values are presented in the Table.

Compared to control, $\mathrm{K}$ and coagulation times $(\mathrm{r}+\mathrm{k})$ decreased significantly $(P<0.05)$ and MA and TEG index increased significantly after magnesium therapy $(P<0.01)$. R time and alpha angle did not change significantly. LY60 related to fibrinolysis was not significantly different before and after magnesium therapy (Figure; Table).

The serum magnesium concentration increased significantly after magnesium therapy to $2.8 \pm 0.9$ $\mathrm{mg} \cdot \mathrm{dL}^{-1}$ from $1.8 \pm 0.8 \mathrm{mg} \cdot \mathrm{dL}^{-1}$ before magnesium therapy (normal ranges of serum magnesium concentration are 1.9 to $\left.3.1 \mathrm{mg} \cdot \mathrm{dL}^{-1} ; P<0.01\right)$.

TABLE Thromboelastographic variables before and after magnesium therapy

\begin{tabular}{|c|c|c|c|c|}
\hline & Normal ranges & Pre- $\mathrm{MgSO}_{4}$ therapy & Post- $\mathrm{MgSO}_{4}$ therapy & Pvalues \\
\hline $\mathrm{R}$ time (second) & $570-840$ & $1060.1 \pm 421.0$ & $907.6 \pm 276.7$ & 0.097 \\
\hline K time (second) & $240-390$ & $641.6 \pm 505.9$ & $464.6 \pm 387.7$ & 0.01 \\
\hline $\begin{array}{l}\text { Coagulation time }(\mathrm{r}+\mathrm{k}) \\
\text { (second) }\end{array}$ & $810-1220$ & $1664.7 \pm 772.5$ & $1362.2 \pm 487.1$ & 0.03 \\
\hline Alpha angle $\left(^{\circ}\right)$ & $29-43$ & $29.2 \pm 14.6$ & $35.6 \pm 13.3$ & 0.07 \\
\hline $\mathrm{MA}(\mathrm{mm})$ & $48-60$ & $38.5 \pm 13.5$ & $45.3 \pm 12.2$ & 0.008 \\
\hline TEG index & $-3.0-+3.0$ & $-3.4 \pm 2.6$ & $-1.9 \pm 1.8$ & 0.005 \\
\hline LY60 (\%) & less than 15 & $3.2 \pm 2.1$ & $3.5 \pm 2.4$ & 0.714 \\
\hline
\end{tabular}

Values are mean $\pm \mathrm{SD} . \mathrm{MgSO}_{4}=$ magnesium sulfate; $\mathrm{MA}=$ maximal amplitude . 

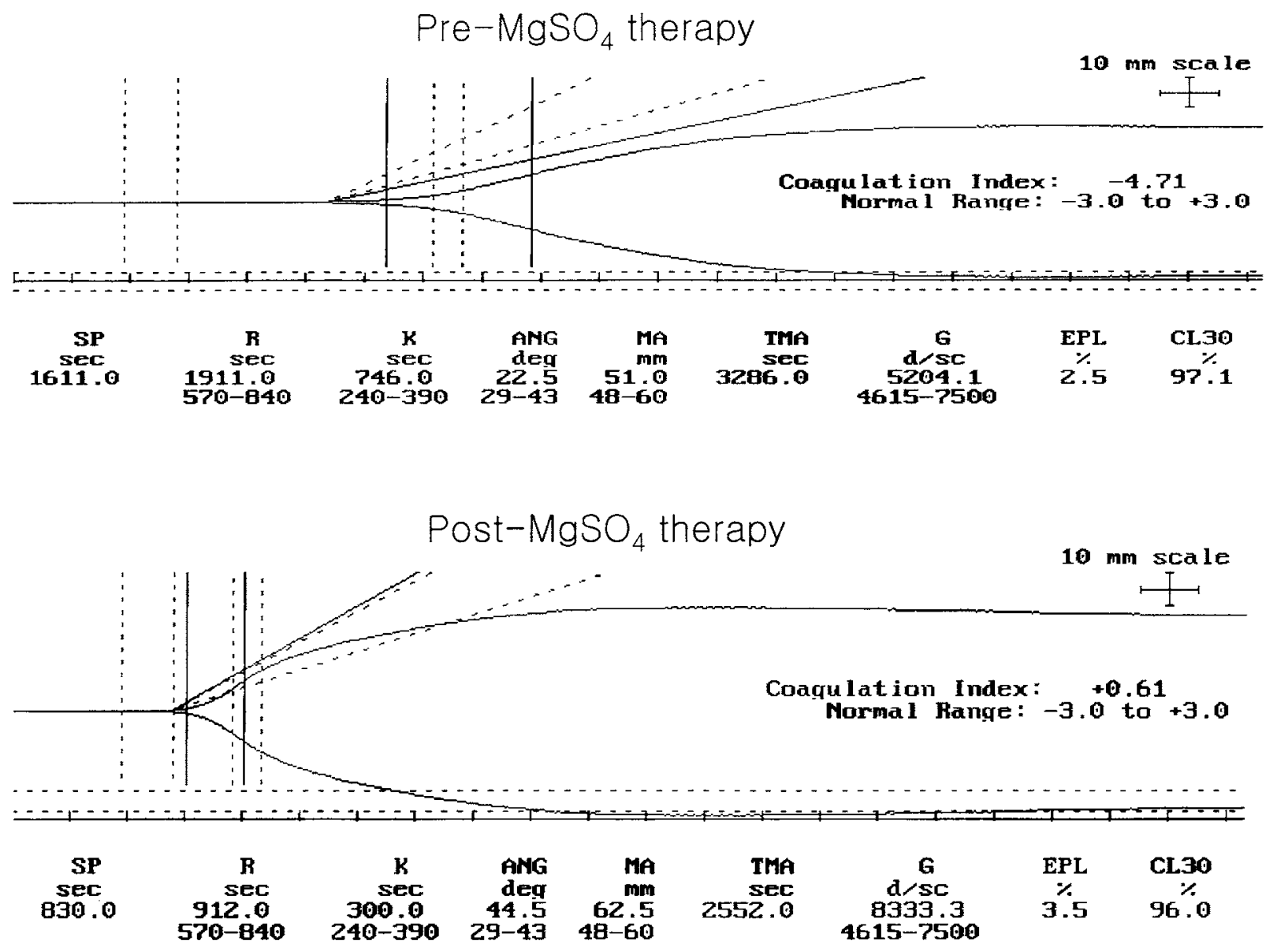

FIGURE Typical thromboelastographic (TEG) traces before and after magnesium therapy. The TEG showed a general hypocoagulable state before magnesium therapy (upper) that improved towards normal after magnesium therapy (lower).

\section{Discussion}

The most significant finding of this preliminary study was that magnesium improved TEG findings of general hypocoagulability in patients about to undergo liver transplantation.

Magnesium is an important factor inhibiting cardiac cell excitation and maintaining stability of the cardiovascular system by controlling the migration of ions including sodium, calcium and potassium through the cell membrane. ${ }^{8}$ Hypomagnesemia is induced in patients with end-stage liver disease due to various reasons; thus, in order to avoid adverse effects of this condition on the cardiovascular system, magnesium supplementation during liver transplantation is considered positively. ${ }^{1,2}$

Magnesium is known to play an important role in the coagulation cascade. Sekiya et $a .^{4}{ }^{4}$ reported that magnesium at physiologic concentrations activates all processes related to factor IX by promoting the biochemical function of factor IX and the activity of factor X under the presence of factor IXa and described that magnesium is an important factor promoting coagulation by activating the factor VIIa-tissue factor complex. Matsuno et al..$^{5}$ also reported that magnesium is an essential element in the activation of thrombin and collagen, promoting platelet aggregation and having coagulation activity. In a clinical study, Serebruany et $a .^{6}$ reported that magnesium therapy improved coagulation by promoting platelet aggregation and decreasing the concentrations of protein $S$ and protein $\mathrm{C}$.

In accordance with our hypothesis and based on previous data, we found that magnesium therapy improved coagulation in patients about to undergo liver transplantation who showed TEG evidence of hypocoagulability. The fact that end-stage liver disease 
patients show TEG findings of general hypocoagulability had already been reported. ${ }^{9-11}$ Our finding of decreased $\mathrm{K}$ and coagulation times $(\mathrm{r}+\mathrm{k})$ after magnesium therapy was considered the result of increased early fibrin formation and improved speed of crosslinking. Increased MA was thought to be a result of improved clot strength secondary to improved function of platelets. The increased TEG index suggests an overall improvement in coagulation.

No significant change was seen on the TEG when healthy volunteers were treated with magnesium. ${ }^{12}$ The claim that the effect of magnesium on the coagulation system is insignificant is based on an in vitro study. ${ }^{13}$ On the other hand, the R time decreased significantly after magnesium therapy in pre-eclamptic women. ${ }^{14}$ Thus, the effect of magnesium therapy on the TEG is still debated. These differing results suggest that magnesium may have different actions when coagulation is normal and abnormal. As shown in our study, magnesium improves TEG variables in patients with end-stage liver disease and hypomagnesemia.

We diluted $1.5 \mathrm{~g}$ of $\mathrm{MgSO}_{4}$ with $100 \mathrm{~mL}$ of normal saline and infused the solution in five minutes. Magnesium was mixed into a small volume of saline because large volumes may either induce bleeding by diluting coagulation factors or promote coagulation by destroying the thrombin and antithrombin balance, as reported by Ruttmann et al. ${ }^{15}$

Our results must be interpreted with caution. First, ionized magnesium is important physiologically among the different forms of magnesium present in the body. However, we did not measure ionized magnesium so that we could not confirm whether TEG changes after magnesium therapy were due to ionized or non-ionized magnesium. Second, TEG used to monitor changes in coagulation after magnesium therapy cannot measure the physiologic and biochemical interactions occurring between platelets and the vascular endothelium. Third, this study was performed to examine the effect of the magnesium therapy on TEG while ruling out the effect of other various factors affecting TEG. Thus, TEG findings prior to (control) and after magnesium therapy in the same patient were compared. However, we must admit that this study was not randomized, and does not give any details on clinical outcome. As such, it should be considered preliminary to a formal randomized controlled study.

In conclusion, we found that magnesium therapy improved the overall TEG findings in patients about to undergo liver transplantation. Further studies will be needed to investigate the effect of magnesium therapy and the improvement of TEG variables on blood product requirements during liver transplantation.

\section{References}

1 Diaz J, Acosta F, Parrilla P, et al. Serum ionized magnesium monitoring during orthotopic liver transplantation. Transplantation 1996; 61: 835-7.

2 Bennett $M W$, Webster NR, Sadek SA. Alterations in plasma magnesium concentrations during liver transplantation. Transplantation 1993; 56: 859-61.

3 Ranasinghe DN, Mallett SV. Hypomagnesaemia, cardiac arrhythmias and orthotopic liver transplantation. Anaesthesia 1994; 49: 403-5.

4 Sekiya F, Yoshida M, Yamashita T, Morita $T$. Magnesium (II) is a crucial constituent of the blood coagulation cascade. Potentiation of coagulant activities of factor IX by $\mathrm{Mg}^{2+}$ ions. J Biol Chem 1996; 271 : 8541-4.

5 Matsuno K, Koyama M, Takeda H, et al. Cytosolic free magnesium concentration in human platelets. Thromb Res 1993; 69: 131-7.

6 Serebruany VL, Herzog WR, Schlossberg ML, Gurbel PA. Bolus magnesium infusion in humans is associated with predominantly unfavourable changes in platelet aggregation and certain haemostatic factors. Pharmacol Res 1997; 36: 17-22.

7 Samama CM, Thiry D, Elalamy I, et al. Perioperative activation of hemostasis in vascular surgery patients. Anesthesiology 2001; 94: 74-8.

8 Fawcett WJ, Haxby EJ, Male DA. Magnesium: physiology and pharmacology. Br J Anaesth 1999; 83: 302-20.

9 Kang YG, Martin DJ, Marquez J, et al. Intraoperative changes in blood coagulation and thrombelastographic monitoring in liver transplantation. Anesth Analg 1985; 64: 888-96.

10 McNicol PL, Liu G, Harley ID, et al. Patterns of coagulopathy during liver transplantation: experience with the first 75 cases using thrombelastography. Anaesth Intens Care 1994; 22: 659-65.

11 Gillies BS. Thromboelastography and liver transplantation. Semin Thromb Hemost 1995; 21(Suppl 4): 45-9.

12 Ames WA, McDonnell N, Potter D. The effect of ionised magnesium on coagulation using thromboelastography. Anaesthesia 1999; 54: 999-1006.

13 James MF, Neil G. Effect of magnesium on coagulation as measured by thrombelastography. Br J Anaesth 1995; 74: 92-4.

14 Harnett MJ, Datta S, Bhavani-Shankar K. The effect of magnesium on coagulation in parturients with preeclampsia. Anesth Analg 2001; 92: 1257-60.

15 Ruttmann TG, James MF, Viljoen JF. Haemodilution induces a hypercoagulable state. Br J Anaesth 1996; 76: $412-4$. 